\title{
Elimination of fetal mice with sporadic malformations by spontaneous resorption in pregnancies of older females
}

\author{
H. Kalter \\ Children's Hospital Research Foundation and Department of Pediatrics, \\ University of Cincinnati College of Medicine, Cincinnati, Ohio 45229, U.S.A.
}

\begin{abstract}
Summary. The frequency of offspring with sporadic spontaneous malformations in $\mathrm{A} / \mathrm{JK} \mathrm{t}$ mice was significantly smaller in litters from older mothers than in litters from younger mothers. Simultaneously the fetal resorption rate was significantly larger in the older than the younger mothers. The number of 'excess' fetal deaths in the older group apparently accounted for most, if not all, of the reduced malformation rate in their surviving offspring. It therefore seems that the aged uterus and the abnormal fetus are involved in the process by which such offspring are eliminated.
\end{abstract}

\section{Introduction}

Many spontaneously aborted human embryos and fetuses are physically malformed or chromosomally aberrant or both (Carr, 1971; Miller, 1975). The loss of such conceptuses reduces the frequency of congenital malformations and chromosomal abnormalities to a small fraction of what it would otherwise be. However, even this natural method of preventing birth defects is imperfect, and some abnormal conceptuses still reach term. Improvement of the method, and further reduction in the frequency of defective newborn infants, must await better understanding of why abnormal fetuses are aborted.

It is well known that as females of various species of laboratory animals get older they have smaller litter sizes (Finn, 1970; Talbert, 1971), and that in stocks with sporadic malformations the frequency of these abnormalities is often reduced in litters from older females (Parsons, 1963; Kalter, 1971). For the most part, however, the relation of these two phenomena to each other has been conjectural, since there is little direct evidence tying them together. The present study attempted to remedy this deficiency.

\section{Materials and Methods}

Two unrelated spontaneous congenital malformations occur quite often in A/JKt mice-cleft lip, usually accompanied by cleft palate, and open eyelid (Kalter, 1968). Kalter (1975) noted that their frequency declined with advancing maternal age and birth order (which were significantly correlated; $r=0.66$ ), while that of prenatal death (resorption) increased.

This inverse relation has now been re-examined in greater detail, first by comparing the malformation and resorption frequencies in the litters of younger and older females; and second by making a direct comparison between these phenomena within individual litters. For the latter purpose, the data were Freeman-Tukey arcsin transformed and examined by simple linear regression. The data are from 235 litters containing 2163 implantations and 1824 surviving fetuses, of the 1st to 7 th pregnancies of $\mathrm{A} / \mathrm{JKt}$ mice, $71-431$ days old at mating, killed 1 or 2 days before expected parturition. Although there was a decided sex difference in the frequency of the defects (female offspring predominating for cleft lip-palate, males for open eyelid), the decline in frequency with maternal age and parity occurred in both sexes to about the same degree (H. Kalter, unpublished), and hence the data for them were combined for all analyses. 


\section{Results and Discussion}

The malformation and resorption rates in litters from females of different ages at conception are recorded in Table 1; a decrease in the former and increase in the latter in older females are clear. The data were therefore divided according to (1) maternal age, into a group of less than 250 days old, and a group 250 days and older; and (2) resorption rate, again into 2 groups, one less than $25 \%$ resorbed, and the other $25 \%$ and greater (Table 2). Differences between the groups were analysed by $\chi^{2}$ tests.

Table 1. Frequency of cleft lip-palate (CLP), open eyelid (OL), and fetal resorption in litters of A/JKt female mice of different age at conception

\begin{tabular}{|c|c|c|c|c|c|c|c|}
\hline \multirow{2}{*}{$\begin{array}{r}\text { Maternal } \\
\text { age (days) }\end{array}$} & \multirow{2}{*}{$\begin{array}{l}\text { No. of } \\
\text { litters }\end{array}$} & \multicolumn{2}{|c|}{ Implantations } & \multirow{2}{*}{$\begin{array}{c}\text { Resorbed } \\
\text { fetuses }(\%)\end{array}$} & \multirow{2}{*}{$\begin{array}{l}\text { No. of } \\
\text { surviving } \\
\text { offspring }\end{array}$} & \multirow{2}{*}{$\begin{array}{c}\text { Fetuses } \\
\text { with CLP }(\%)\end{array}$} & \multirow{2}{*}{$\begin{array}{c}\text { Fetuses with } \\
\text { OL }(\%)\end{array}$} \\
\hline & & No. & Mean & & & & \\
\hline$<150$ & 67 & 630 & $9 \cdot 39$ & $78(12.4)$ & 552 & $69(12 \cdot 5)$ & $78(14 \cdot 1)$ \\
\hline $150-199$ & 63 & 586 & $9 \cdot 30$ & $88(15 \cdot 0)$ & 498 & $65(13.0)$ & $96(18 \cdot 3)$ \\
\hline $200-249$ & 50 & 471 & $9 \cdot 44$ & $64(13 \cdot 6)$ & 407 & $43(10 \cdot 6)$ & $58(14 \cdot 2)$ \\
\hline $250-299$ & 31 & 284 & $9 \cdot 16$ & $54(19.0)$ & 230 & $14(6 \cdot 1)$ & $27(11 \cdot 7)$ \\
\hline$\geqslant 300$ & 24 & 192 & $8 \cdot 00$ & $55(28 \cdot 6)$ & 137 & $9(6.6)$ & $12(8 \cdot 8)$ \\
\hline Total & 235 & 2163 & $9 \cdot 20$ & $339(15 \cdot 7)$ & 1824 & $200(11 \cdot 0)$ & $266(14 \cdot 6)$ \\
\hline
\end{tabular}

Table 2. Malformation frequency (cleft lip-palate, CLP, and open eyelid, $O L$ ) in litters from young and old females, and in litters with high and low resorption rates

\begin{tabular}{|c|c|c|c|c|c|c|c|c|}
\hline \multirow{2}{*}{$\begin{array}{c}\text { Maternal } \\
\text { age (days) }\end{array}$} & \multirow{2}{*}{$\begin{array}{l}\text { No. of } \\
\text { litters }\end{array}$} & \multicolumn{2}{|c|}{ Implantations } & \multirow{2}{*}{$\begin{array}{c}\text { Resorbed } \\
\text { fetuses }(\%)\end{array}$} & \multirow{2}{*}{$\begin{array}{l}\text { No. of } \\
\text { surviving } \\
\text { offspring }\end{array}$} & \multirow{2}{*}{$\begin{array}{l}\text { No. with } \\
\text { CLP (\%) }\end{array}$} & \multirow{2}{*}{$\begin{array}{l}\text { No. with } \\
\text { OL }(\%)\end{array}$} & \multirow{2}{*}{$\begin{array}{l}\text { No. with CLP } \\
\text { OL or both }(\%)\end{array}$} \\
\hline & & No. & Mean & & & & & \\
\hline \multicolumn{9}{|c|}{ Litters with $<25 \%$ resorbed fetuses } \\
\hline$<250$ & 143 & 1356 & $9 \cdot 48$ & $123(9 \cdot 1)$ & 1233 & $147(11 \cdot 9)$ & $199(16 \cdot 1)$ & $309(25 \cdot 1)$ \\
\hline $250+$ & 31 & 264 & $8 \cdot 52$ & $29(11 \cdot 0)$ & 235 & $17(7 \cdot 2)$ & $27(11 \cdot 5)$ & $40(17 \cdot 0)$ \\
\hline Total & 174 & 1620 & $9 \cdot 20$ & $152(9 \cdot 4)$ & 1468 & $164(11 \cdot 2)^{d}$ & $226(15 \cdot 4)^{e}$ & $349(23 \cdot 8)^{f}$ \\
\hline \multicolumn{9}{|c|}{ Litters with $>25 \%$ resorbed fetuses } \\
\hline$<250$ & 37 & 331 & $8 \cdot 94$ & $107(32 \cdot 3)$ & 224 & $30(13 \cdot 4)$ & $28(12 \cdot 5)$ & $52(23 \cdot 2)$ \\
\hline $250+$ & 24 & 212 & $8 \cdot 83$ & $80(37 \cdot 7)$ & 132 & $6(4 \cdot 5)$ & $12(9 \cdot 1)$ & $16(12 \cdot 1)$ \\
\hline Total & 61 & 543 & 8.90 & $187(34 \cdot 4)$ & 356 & $36(10 \cdot 1)^{d}$ & $40(11 \cdot 2)^{e}$ & $68(19 \cdot 1)^{\mathrm{f}}$ \\
\hline \multicolumn{9}{|c|}{ Total } \\
\hline$<250$ & 180 & 1687 & $9 \cdot 37$ & $230(13.6)^{a}$ & 1457 & $177(12 \cdot 1)^{\mathrm{b}}$ & $227(15.6)^{\mathrm{c}}$ & $361(24 \cdot 8)^{g}$ \\
\hline $250+$ & 55 & 476 & $8 \cdot 65$ & $109(22 \cdot 9)^{\mathbf{a}}$ & 367 & $23(6 \cdot 3)^{b}$ & $39(10.6)^{\mathrm{c}}$ & $56(15 \cdot 3)^{8}$ \\
\hline Total & 235 & 2163 & $9 \cdot 20$ & $339(15 \cdot 7)$ & 1824 & $200(11 \cdot 0)$ & $266(14 \cdot 6)$ & $417(22 \cdot 9)$ \\
\hline
\end{tabular}

${ }^{\mathrm{a}, \mathrm{z}} P \ll 0.001 ;{ }^{\mathrm{b}} P \ll 0.01 ;{ }^{\mathrm{c}} P<0.025 ;{ }^{\mathrm{d}, \mathrm{e}, \mathrm{f}} P>0.05$.

There was a much greater resorption rate in the older group than the younger; and the overall malformation frequencies, especially of cleft lip-palate were in the opposite direction, and were significantly smaller in the older than the younger animals. However, an apparent absence of a direct relation between the malformation and resorption rates was indicated by regression analyses, which failed to uncover a significant connection between these phenomena within individual litters. The differences in the malformation rates between the groups differing in resorption rate were not statistically significant, but were suggestive and gave the impression of a possible additive action of maternal age and resorption level (Table 2). 
Table 3. Frequency, in older females, of resorptions and malformations in litters with and without abnormal and resorbed offspring, respectively

\begin{tabular}{|c|c|c|}
\hline & Absent & Present \\
\hline & \multicolumn{2}{|c|}{ Abnormal offspring } \\
\hline No. of litters & 24 & 31 \\
\hline No. of implantations & 196 & 280 \\
\hline \multirow[t]{2}{*}{ No. resorbed $(\%)$} & $55(28 \cdot 1)^{*}$ & $54(19 \cdot 3)^{*}$ \\
\hline & \multicolumn{2}{|c|}{ Resorptions } \\
\hline No. of litters & 25 & 30 \\
\hline No. of offspring & 87 & 280 \\
\hline No. abnormal $(\%)$ & $16(18 \cdot 4) \dagger$ & $40(14.3) \dagger$ \\
\hline
\end{tabular}

$* P<0.05 ; \quad+P>0.05$

Another way of examining the data again yielded conflicting results. Litters from females 250 days and older were divided into those with and without abnormal offspring. The results were positive, with a significantly smaller resorption rate in the former than the latter (Table 3 ). Reversing the analysis and comparing the abnormality rate in litters with and without resorptions again gave suggestive but not significant results (Table 3 ).

Thus despite the undeniable parallel-occurrence of a general decline in malformation frequency and rise in resorption rate with advancing maternal age, no clear evidence emerged of a direct relation between these events. This apparent contradiction is perhaps due to the connection between these events within each litter being dispersed and variable, and hence failing to reveal itself through this statistical procedure.

The basis of the reduced malformation frequency was either the differential postimplantational elimination of abnormal conceptuses relative to normal ones or their decreased conception. The mean number of implantations (number of survivors + number resorbed/number of litters) in the older group of females was significantly smaller than that in the younger animals $(8.65 \pm 0.25$ versus $9.37 \pm 0.12 ; t=2 \cdot 89, P<0.02$ ), but this reduction (of about $7.6 \%$ ) is insufficient to account for any but a minute part of the decreased malformation frequency. On the other hand, as noted above, the postimplantational resorption rate in the older group was about $70 \%$ greater than in the younger and can easily account for the almost $40 \%$ decrease in the total number of defective offspring ( 24.8 to $15.3 \%$, recalling that $11.75 \%$ of fetuses had both defects). Therefore, if it is assumed that the increased resorption rate in the older group was responsible for (1) $75 \%$ or (2) $100 \%$ of the reduction in the total number of malformed offspring, restoring these offspring would increase the frequency to (1) $21.6 \%$ or (2) $24.3 \%$, approaching that in the younger group.

These calculations assume that the resorption rate occurring in the younger females, though rather substantial $(13.6 \%$ ), was basal and, being equal in normal and abnormal conceptuses, did not contribute to diminishing the malformation frequency. Therefore all or nearly all of the 'excess' resorptions in the older females must have been of abnormal offspring. However, if it is postulated that the resorption rates of normal and abnormal conceptuses in the younger group were not identical, and that the rate of normal ones was, say, half that of abnormal conceptuses, calculations show these rates to have been 10.7 and $21.5 \%$, respectively. If this rate for normal conceptuses or 1.5 or 2.0 times it, is then taken as having occurred in normals in the older group, the resorption rates for abnormal conceptuses would be $56 \cdot 2,47 \cdot 2$, and $30.0 \%$, respectively. Thus under these conditions even a modest increase in the resorption rate can account for the substantial reduction in the malformation frequency.

It is important to know when the death of the abnormal embryos and fetuses occurred. As discussed above, the reduced implantation rate in the older group is inadequate to explain the fewer malformed young (the difference between the mean number of implantations in the two resorptionrate groups is even less: $9 \cdot 31$ versus 8.90 ). The death of abnormal offspring can only therefore have 
occurred after the time of implantation. Since the frequency of cleft lip-palate does not change during the last week of pregnancy in A/JKt mice (see citations in Kalter, 1975), the loss of conceptuses with this defect must take place during the 2 nd week. The time of loss of young with open eyelid (more properly, with 'latent' open eyelid) is less clear, because this defect is not manifest until Days 17-18 of gestation, when normal eyelid closure occurs.

Finally, this study has provided evidence that advanced maternal age, which is considered an adverse condition (Biggers, 1969), can lead to differential death of malformed fetuses. It is obvious that both the aged uterus and the abnormal fetus were involved in the eliminatory process, and that understanding their interrelation may lead to methods for facilitating the spontaneous abortion of defective fetuses.

\section{References}

Biggers, J.D. (1969) Problems concerning the uterine causes of embryonic death, with special reference to the effects of ageing of the uterus. J. Reprod. Fert., Suppl. 8, 27-43.

CARR, D.H. (1971) Genetic basis of abortion. A. Rev. Genet. 5, 65-80.

FinN, C.A. (1970) The ageing uterus and its influence on reproductive capacity. J. Reprod. Fert., Suppl. 12, 31-38.

KALTER, H. (1968) Sporadic congenital malformations of newborn inbred mice. Teratology 1, 193-199.

KaLTER, H. (1971) Effects of litter size and maternal and temporal factors on the frequency of spontaneous cleft lip and open eyelid in newborn $A / J$ mice. J. Dent. Res. 50, 1442-1446.

Kalter, H. (1975) Prenatal epidemiology of spontaneous cleft lip and palate, open eyelid, and embryonic death in A/J mice. Teratology 12, 245-257.

MilleR, J.R. (1975) Some epidemiological aspects of teratogen detection. Mutat. Res. 33, 45-54.

Parsons, P.A. (1963) Congenital abnormalities and competition in man and other mammals at different maternal ages. Nature, Lond. 198, 316-317.

TALBerT, G.B. (1971) Effect of maternal age on postimplantation reproductive failure in mice. J. Reprod. Fert. 24, 449-452.

Received 14 February 1978 